\title{
Liberal reforms \& economic growth: Current issues and interrelations
}

\author{
Hung Tran Van \\ Vietnam National University of Forestry, Southern Campus, \\ Ho Chi Minh city, Vietnam \\ tranbungln2@gmail.com
}

\author{
Ai Tran Huu \\ $V$ an Hien University, \\ Ho Chi Minh city, Vietnam \\ aibuutran@gmail.com \\ Denis Ushakov \\ International College Suan Sunandha Rajabhat University, \\ Bangkok, Thailand \\ fintaliano@yandex.ru
}

Abstract. Economic liberalization in today's conditions is not so much an effective tool of national economy stimulation but is rather a precondition for its connection to the world markets and global economic space overall. The paper investigates economic effectiveness of liberalization that is determined by a variety of conditions and features in its implementation. Basing on the analysis of correlation between economic liberalization dynamics and macroeconomic indicators of the selected countries of the world, the magnitude of liberal reforms' stimulating effect in the early 21 st century is estimated, and theoretical conclusions regarding liberal economic reforms potential in our time are offered along with the recommendations on strategic priorities and tactical tools to improve national business environment and increase global economic attractiveness.

Keywords: business liberalization, government regulation, reform, modernization, global economy.

JEL Classification: F01, F29, H10. 


\section{INTRODUCTION}

Transformation of the world economy into a complex construct of mutually integrated national economies, transnational chains of consumer value formation and distribution is the main trend of the last forty years of economic progress. It determines a number of significant other transformations, namely, in the field of state economic regulation. On the one hand, it requires regulatory functions to be transferred to the level of international organizations with all necessary competences, on the other hand, it devaluates the classical paternalistic measures of state intervention into the national economic system, also defining new principles and guidelines for government-business interactions, in which both directions and tools for state regulatory competences are implemented.

The multisystem of the world economy, diversity of countries' positioning in the global division of labor determine the ambiguity of state regulation reforms (either initiated by country's government, or imposed from the outside). The consequences of these reforms also vary widely - from rapid economic growth, drastic increase in national living standards to nearly absolute loss of economic sovereignty and national control over strategic resources, accompanied with a wide range of social problems.

However, even a cursory analysis of liberal reforms' results shows the presence of certain patterns, consideration of which can potentially improve the quality of economic forecasting in the course of macroeconomic reforms.

This generally determines the relevance and the subsequent purpose of the study - to determine the countries' economic achievements (primarily in terms of their material well-being and integration into the world economic processes) in their relation to efficiency of liberal reforms' implementation during 20002014.

The research objectives accordingly are stated as follows:

- To explain liberalization as one of the global trend in state economic regulation; to characterize its structural and functional manifestations;

- On the basis of macroeconomic indicators and also Doing Business indicators (DB) to analyze the economic liberalization dynamics in the selected countries of the world as well as manifestations of the results from these reforms in the analyzed countries;

- To identify the patterns in the reforming economic systems' reactions to liberalization processes and also to evaluate the synchronicity of this reaction in groups of countries (the selected countries have been grouped by geography and also by the level of their material well-being);

- To form conclusions on feasibility and factors of liberal reforms' economic efficiency.

\section{THEORETICAL BACKGROUND OF THE STUDY}

Limited ability of markets self-regulation (Hsueh, 2015; Fligstein, 1996) inevitably allows concluding an objective existence of mixed economy, which is based on both market and government regulation. Thus the most of today's researchers in economic theory are not debating on the needs (no needs) of State presence in economy, but on the ratio of this presence in different economic conditions.

The analysis of the state economic regulations' evolution from the "night watchman" and international trade administrator (Stigler, 1971), money supply regulator (French-Davis, 2014) and maintainer of competitive business environment (Lewa, 2006) shows, firstly, growing role of Government functions' concretization, and secondly, the gradual movement of the state regulation objects from final phases of the production process to its beginning.

In modern science, problems of the correlation of economic growth and the liberalization dynamics of retain relevance and significance. For example, Bumann, S., Hermes, N. \& Lensink, R. (2013) conducted a systematic analysis of the relationship between financial liberalization and economic growth, determined 
that on average, there is a positive effect of the financial liberalization on growth, the significance of this effect is only weak. Experts of International Monetary Fund - Edison, H., Klein, M., Ricci, L., Sløk, T (2004) discussed the effects of capital and market liberalization on economic growth, detailed measures of reflecting differences in the country coverage, sample periods, indicators of liberalization, and found some positive effects (Fidrmuc \& Kostagianni, 2015).

At the same time, for example, Chanda, A. (2005) tested the hypotheses that capital controls have no effect on economic growth, arguing that this conclusion emerges from a failure to account for underlying differences across countries with similar degrees of capital controls. Tornell, A., Westermann, F., Martinez, L. (2006) examined the positive relationship between financial liberalization and economic growth, presented a model that shows why in the countries with severe credit market imperfections, liberalization leads to higher growth and, as a byproduct, to financial fragility.

The stimulating effect of trade liberalization on economic growth was analyzed by Mattoo, A., Rathindran, R. (2006); Fitzová, H. and Zídek, L. (2015). Their estimates suggest that the countries up to 1.5 percentage points faster than other countries. Francois, J., Schuknecht, L. (2009) formalized the argument that trade, through the fostering of financial market integration, may yield important long-run effects, suggested that trade has a quantitatively large and robust, but only moderately statistically significant, positive effect on income.

It is also worthwhile to highlight studies of the liberal reforms stimulating impact in various countries of the world, which methods and results formed the basis of this work. For example, Bühler, S., Helm, M., Lechner, M. (2008) estimated and proved the relevant effect of trade liberalization on growth in Switzerland. At the same time in India, in the short run, trade liberalization has a beneficial impact on the rich and fastgrowing middle-income states (Naranpanawa \& Arora, 2014).

Bouzid Amaira, (2016) estimated cointegration and causality between financial liberalization policy and economic growth in Tunisia, and also found the existence of a long-term relationship between the financial liberalization index and economic growth. Similar studies were conducted in the group of countries of the Asia-Pacific region (Lewa, 2006) and Eastern Europe (Cristescu, 2010).

We can identify structural and functional manifestations of economy liberalization Structurally economic liberalization can be understood as manageable process of giving greater abilities for market selforganization,. Functionally, the economic liberalization is defined as a measured value of state competences in Government regulation of particular aspects of business practice (Dinopoulos \& Lane, 1992).

Functional liberalization traditionally has short period of implementation in terms of economic growth, structural liberal transformations are mostly focused on the long term.

Structural liberal reformations are usually realized in crisis periods (Mickiewicz, 2009), due to their orientation on economy modernization, creation of globally competitive national industries and types of activity. Functional liberalization is practiced usually just to stimulate economic development, to reach fast economic results. Phases of structural and functional manifestations are alternating, that is broadly related with the dialectical methodology of "quantity into quality" transformation.

\section{ECONOMIC LIBERALIZATION RESULTS IN TODAY'S WORLD}

Materials and Methods should be described with sufficient details to allow others to replicate and build on published results. Please note that publication of your manuscript implicates that you must make all materials, data, computer code, and protocols associated with the publication available to readers. Please disclose at the submission stage any restrictions on the availability of materials or information. New methods and protocols should be described in detail while well-established methods can be briefly described and appropriately cited. To conduct the study we used the results of annual World Bank experts' evaluations 
Doing Business (DB), (Tab.1, 2). Later in the study we use DB indexes as indicators of business liberalization in static and dynamics.

Doing business, 2015

\begin{tabular}{|l|l|l|l|l|l|}
\hline Rank & Country & Rating & Rank & Country & Rating \\
\hline 1 & New Zealand & 86,79 & 127 & Guinea & 45,54 \\
\hline 2 & Denmark & 84,4 & 128 & Cameroon & 44,11 \\
\hline 3 & Korea, R. & 83,88 & 129 & Nigeria & 44,03 \\
\hline 4 & USA & 83,13 & 130 & Bangladesh & 43,4 \\
\hline 5 & United Kingdom & 82,46 & 131 & Congo & 41,88 \\
\hline 6 & Sweden & 81,72 & 132 & Liberia & 40,1 \\
\hline 7 & Norway & 81,61 & 133 & Angola & 39,64 \\
\hline 8 & Finland & 81,05 & 134 & Chad & 38,22 \\
\hline 9 & Canada & 80,9 & 135 & Congo ZA & 38,14 \\
\hline 10 & Australia & 80,08 & 136 & Eritreya & 27,61 \\
\hline
\end{tabular}

Source: countries rating, calculated by Doing Business expert group

Table 2

Doing business ratings' change for recent years

\begin{tabular}{|l|l|l|l|l|l|l|l|}
\hline \multirow{2}{*}{ Rank } & \multicolumn{2}{|l|}{ Countries-leaders on DB increasing for } & \multirow{2}{*}{ Rank } & \multicolumn{2}{|l|}{ Countries-outsiders on DB increasing for } \\
& Last 10 years & Last 5 years & $\begin{array}{l}\text { Last 10 } \\
\text { years }\end{array}$ & & Last 10 years & Last 5 years & $\begin{array}{l}\text { Last 10 } \\
\text { years }\end{array}$ \\
\hline 1 & Ukraine & Ukraine & Uzbekistan & 127 & Namibia & Tanzania & Cameroon \\
\hline 2 & Uzbekistan & Uzbekistan & Chad & 128 & Sudan & S.Arabia & Gabon \\
\hline 3 & Burundi & Russia & Tajikistan & 129 & Ghana & Pakistan & Pakistan \\
\hline 4 & Belarus & Tajikistan & Romania & 130 & Saudi Arabia & Gabon & USA \\
\hline 5 & Tajikistan & Chad & Croatia & 131 & Maldives & Lebanon & Maldives \\
\hline 6 & Chad & Guinea & Bosnia & 132 & Pakistan & Ghana & Angola \\
\hline 7 & Russia & Costa Rica & Serbia & 133 & Lebanon & Algeria & Ghana \\
\hline 8 & Kazakhstan & Togo & Costa Rica & 134 & Algeria & Liberia & Algeria \\
\hline 9 & Togo & Moldova & Hungary & 135 & Bangladesh & Maldives & Eritreya \\
\hline 10 & Niger & Romania & B.-Faso & 136 & Eritrea & Eritrea & Liberia \\
\hline
\end{tabular}

Source: made by authors, used data from Doing Business

To mark and compare economic results of business environment modernization we identified macroeconomic indicators combined into three groups:

- Static indicators of countries' material well-being (current level of GDP, GDP per capita and official unemployment);

- Dynamic indicators of countries' material well-being (annual growth of GDP and GDP per capita rates);

- Trade performance of countries (absolute value of the national imports and exports, ratio of exports and imports to national GDP).

All macroeconomic indicators were taken from the World Bank statistics database for 136 countries in 2000 - 2015.

The study was conducted in two stages. At the first stage we tested the correlation between dynamics of business liberalization and economic achievements of the countries of the world divided for 6 groups by their GDP per capita (Tab. 3). 
Considered groups of countries of the world

\begin{tabular}{|l|l|c|c|}
\hline No & \multicolumn{1}{|c|}{ Group } & National GDP per capita, USD & $\begin{array}{c}\text { Number of considered } \\
\text { countries }\end{array}$ \\
\hline 1 & With high income & $>40000$ & 17 \\
\hline 2 & With high average income & $20000-40000$ & 14 \\
\hline 3 & With average income & $10000-20000$ & 17 \\
\hline 4 & With low average income & $5000-10000$ & 24 \\
\hline 5 & With low income & $1000-5000$ & 22 \\
\hline 6 & With very low income & $<1000$ & 22 \\
\hline
\end{tabular}

Source: compiled by the authors

Fig. 1 shows an impact of liberal reforms on economic performance of groups of the countries.

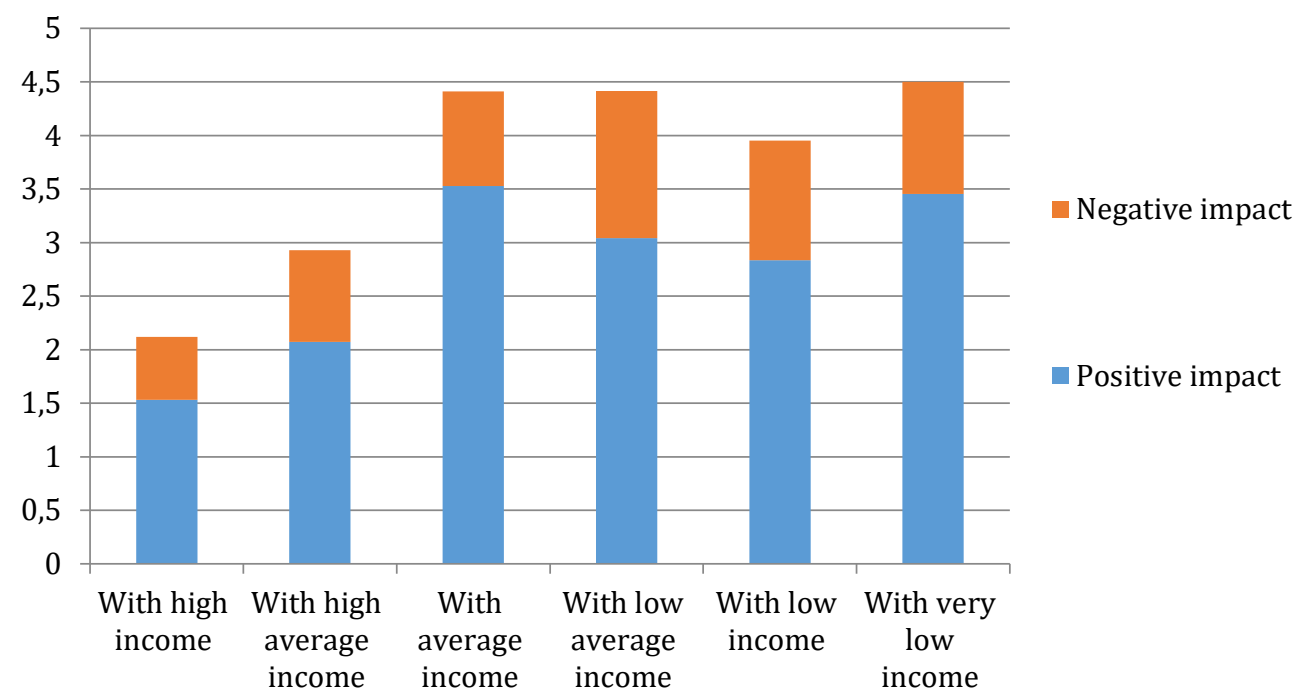

Figure 1. The impact of liberal reforms on the modern countries economic performance

Source: compiled by authors

As shown in Fig. 1, the greatest mostly positive influence business liberalization has in countries with average and low per capita income. It generally follows the effect of diminishing utility in the economic systems.

At the second stage of the study we analyzed effects of economy liberalization in 11 geographical regions (such as: Africa - 36 countries, Latin America - 18 countries, Middle East - 14 countries, Asia-Pacific region - 13 countries, South Asia - 6 countries, countries of former Soviet Union - 11 countries, Eastern Europe - 14 countries, Southern Europe - 6 countries, Western Europe - 8 countries, Northern Europe - 6 countries, North America - 2 countries).

Comparing indices of correlation between economic development and business liberalization in 11 groups of countries we can identify that maximum economic impact (both positive and negative) business liberalization had in the countries of Southern and Eastern Europe, the minimum one - in the US and Canada, as well as in developed countries of North, Central and Western Europe. It is also worth noting that the most positive economic impact business environment liberalization had in Eastern Europe and in 
Asia Pacific region. The greatest negative impact of liberalization in 2010-2016 was typical for Southern Europe and South and Central Asia.

Table 4

Indicators of the correlation between liberalization dynamics and main macroeconomic indicators of countries' groups

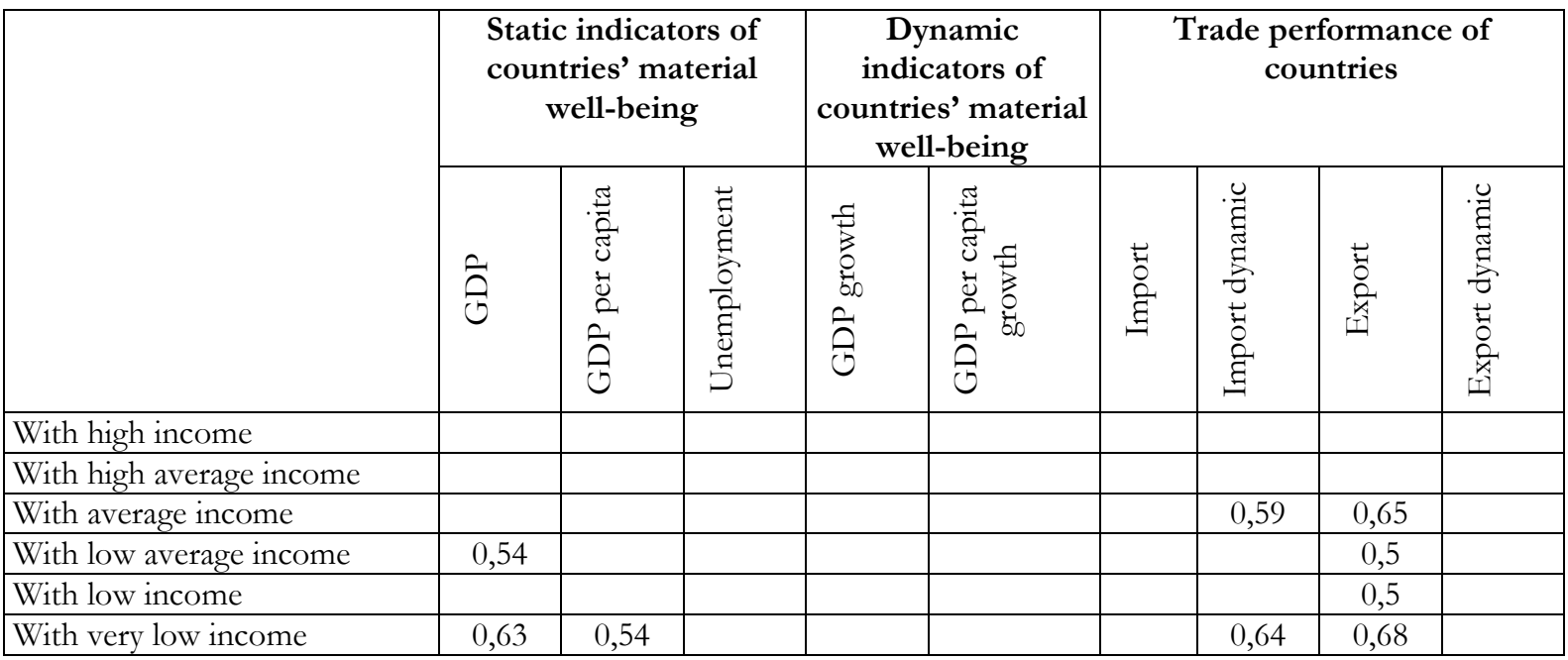

Source: calculated and compiled by the authors

As can be seen the global deepening of business liberalization trend had largely positive macroeconomic effects (exceptions are South Asia and Southern Europe)and mostly defined an economic progress of Eastern Europe, Asia-Pacific and Latin America (Tab. 5).

We can test an effect of business environment liberalization on dynamics of main macroeconomic indicators in 2010-2016. The highest positive impact of economic liberalization was observed in the countries' export opportunities and state of national import. Also liberalization had a positive impact on employment.

Table 5 demonstrates very high level of positive correlation between exports - imports and liberalization dynamics in countries of Africa and Eastern Europe. At the same time economical liberalization doesn't have both positive and negative impacts on the structure and dynamics of exports in the US and Canada. Noticeable positive impact on GDP economic reforms had in Asia Pacific, Latin America and Africa, and high negative correlation is only typical for the countries of Southern Europe. An economic growth's dynamics as a result of business liberalization has significantly accelerated in the CIS and Eastern Europe.

Finally, it is worth noting that in most groups of countries (except CIS countries, South, Central and Western Europe) low, but negative correlation between the liberal reforms dynamics and unemployment was marked. Therefore, in most countries the business environment liberalization is forcing an employment.

African countries have a maximum positive correlation between "doing business" conditions and national exports and imports. Similarly, Latin America and the Middle East countries have a high degree of correlation between the business freedom performance and countries' achievements in world trade,

It is interesting to highlight that significant direct correlation between business development and local population employment was found in the CIS and South Asia's countries. Countries of Asia-Pacific region and CIS also save export and import growth's dependence on internal business regime. 
Table 5

Correlation between business liberalization and main macroeconomic indices in 11 geographical groups of the countries, 2010-2016

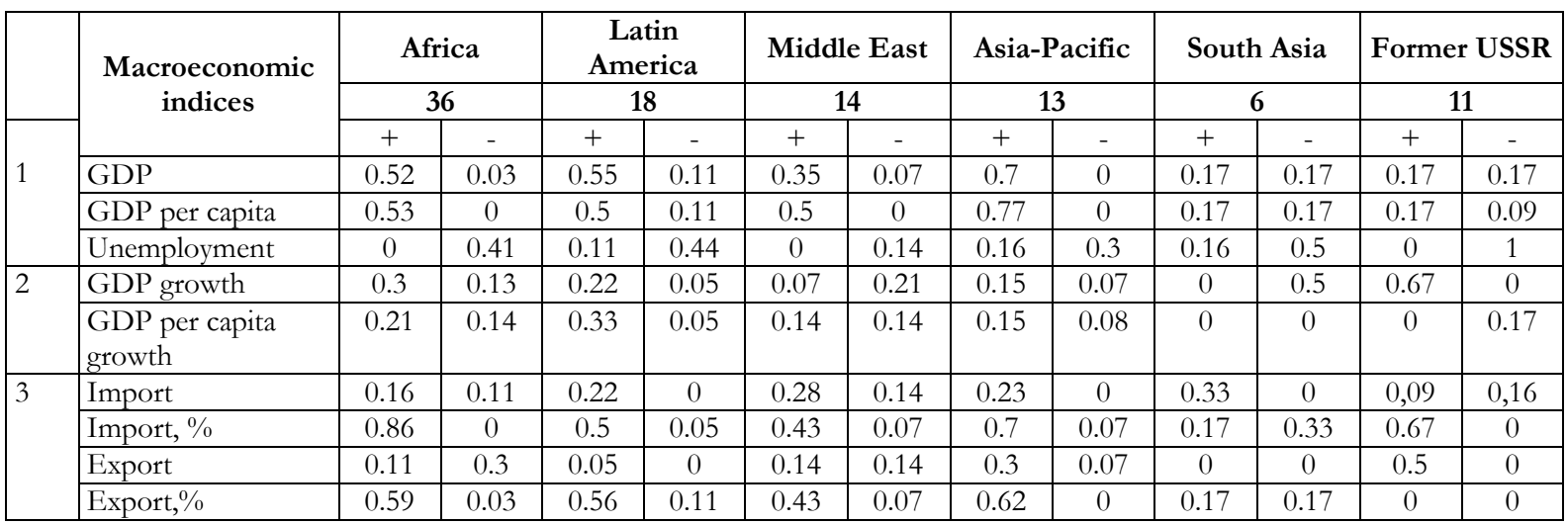

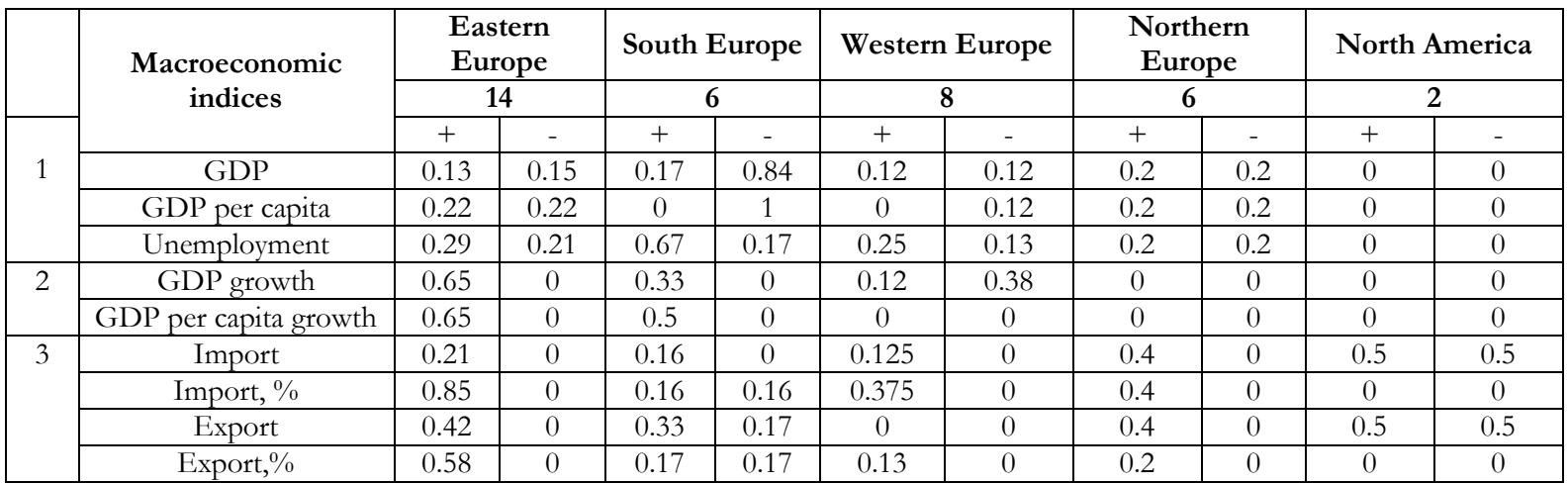

Source: made by co-authors

Assessing the impact of countries' business environment on national GDP growth, we can determine that in the regions where business environment liberalization highly stimulated the national GDP growth (Africa, Latin America, Asia-Pacific) the smallest positive correlation of DB index change with GDP dynamics (in absolute terms) was observed (!). At the same time, the CIS and Eastern Europe countries, where the business liberalization determined the maximum GDP growth (in absolute terms) are outsiders in DB index and dynamics of national product growth correlation. The similar situation is found in the correlation between DB index dynamics and GDP per capita. The business liberalization determines the maximum growth of GDP per capita in Africa, Latin America, the Middle East and the Asia-Pacific region, but the maximum absolute values of GDP per capita in Eastern and Southern Europe.

We can substantiate this by higher rate of population growth in the countries where business liberalization maximum stimulates an economic growth, and by low starting rates of economic development at the time of statistical data collection (2010). As wellknown to ensure the rapid economic growth from low starting marks (especially low level of welfare) is much easier.

However, high levels of economic growth dynamics do not find its incarnation in the highest absolute numbers of both GDP and GDP per capita due to their population growth (in some countries, such as Angola or Kenya - the dynamics of population growth exceeds the dynamics of national economic growth . For example, economic growth of 1.5-2.0\% will ensure the growth of GDP per capita in real terms in Germany, the US or Russia, but not, for example, in Kenya or in Niger where population growth rates are $2.1 \%$ and $3.4 \%$ respectively (CIA World Factbook, 2015). 
Liberal reforms have maximum impact on employment growth in the CIS and South Asia, while in the more economically developed countries of Europe this effect is practically absent.

\section{CONCLUSIONS}

Analyzed correlation between business liberalization dynamics and countries macroeconomic indicators (Tab 4.) allows us to conclude that:

- Business liberalization almost does not impact on the share (\% of GDP) of export and import, while in absolute trade indices we observed positive correlation only in poor and very poor countries;

- GDP growth in absolute terms was typical only for poor and very poor countries.

Business regulation reforms in the countries participating in the world trading system have multidirectional effect.

First of all, we can highlight that there is logic inherent to GDP performance: the countries where liberal business reforms highly impact on the value of export / import are not (at the same time) the countries where economy liberalization defines the exports / imports growth in absolute terms (exception is only Eastern Europe).

The second obvious feature - business liberalization did not affect the import / export growth in Europe (except Eastern) and the United States.

The third feature - the reform of business regulation has determined a significant increasing of exports (only) in the Middle East and imports (only) in the CIS countries.

It confirms an assumption that the market-based instruments of internal economic regulation will facilitate national market adequatization to not local but global, world market priorities.

Global transnational production and distribution systems being closed and high effective networks have established the conditions of national economic systems striving for the universalization, adaptation to global trends which perceived as the only possible alternative of national competitiveness development. National economic system is tightly related with the global financial, information, labor and other markets, and strongly react to factors of global (than national) order.

Therefore, in the coordinates of 21st century the business liberalization has become an instrument of national economic systems integration in the structure of global production and distribution. This mechanism starting at the time of Government economic presence reducing adjusts any national economic system to world's economic priorities; effectively resonates it with the economic factors of the global order.

This theoretical assumption has practical importance, allowing asserting that:

1. If before liberalization was an effective tool to improve local businesses competitiveness in the $21 \mathrm{st}$ century, the required level of liberalization is just a prerequisite for local business admission to the global market, but not its any competitive advantage.

2. If previously liberalizing the economic system, Government could increase an effectiveness of own impact on some industries, in the 21st century liberalization is the tool to activate only those sectors and only those activities, which functioning is interest for global economy (for example, only exports of natural resources, but not high-tech products can develop due to the international trade liberalization in the country).

3. If previously Government could consider the liberalization as a strategic plan of the national income growth (for example, through tax payment's growth or job creation), in the 21st century economic results of liberalization can be easily globalized, denationalized, taken away from the economic jurisdiction of the country on world level, or even nationalized by other states.

4. If in the 20th century Government support of business (e.g., national exporters, national champions, innovative companies) has been a relatively effective tool and often implemented in practice, in the $21 \mathrm{st}$ 
century attempts of state economic incentives (investment, subsidies, benefits) of individual companies or industries are completely inappropriate due to abilities of the national public resources withdrawal to the world market.

These theoretical findings indicate the need of radical revision of the state's market role in the 21st century, which is not only a tool for the preservation of Government efficiency, but also its survival in the era of transnational production and distribution systems development. It is possible that a new vision of the government market role must be based on the project and the network principles, which will combine mobility of connecting active members and controlled objects, resources and regulatory tools, alternate macro-economic and micro-economic guidelines, as well as the traditional liberal and administrative reforming tools that in the new environment may become additional resources of national progress and competitiveness.

\section{REFERENCES}

Amaira, B. (2016). Financial liberalization and economic growth: Evidence from Tunisia. Theoretical \& Applied Economics, 23(4), 243-262.

Buehler, S., Helm, M., \& Lechner, M. (2011). Trade liberalization and growth: Plant-level evidence from Switzerland.Economics Working Paper Series, 1133.

Bumann, S., Hermes, N., \& Lensink, R. (2013). Financial liberalization and economic growth: A meta-analysis. Journal of International Money and Finance, 33, 255-281.

Chanda, A. (2005). The influence of capital controls on long run growth: Where and how much?. Journal of Development Economics, 77(2), 441-466.

CLA World Factbook. (2015). Country Comparison: Birth Rate.

Cristescu, L. (2009). The Effect of Capital Market Liberalization in Eastern Europe: Economic Growth or Financial Crisis (No. 30). Bucharest University of Economics, Center for Advanced Research in Finance and Banking-CARFIB.

Dinopoulos, E., \& Lane, T. D. (1992). Market liberalization policies in a reforming socialist economy. Staff Papers, 39(3), 465-494.

Edison, H. J., Klein, M. W., Ricci, L. A., \& Sløk, T. (2004). Capital account liberalization and economic performance: Survey and synthesis. IMF Staff Papers, 51(2), 220-256.

Fidrmuc, J., \& Kostagianni, S. (2015). Impact of Imf Assistance on Economic Growth Revisited. Economics \& Sociology, 8(3), 32-40.

Fitzová, H., \& Zídek, L. (2015). Impact of trade on economic growth in the Czech and Slovak Republics. Economics \& Sociology, 8(2), 36-50.

Fligstein, N. (1996). Markets as politics: A political-cultural approach to market institutions. American sociological review, 61, 656-673. doi:10.2307/2096398.

Francois, J. F., \& Schuknecht, L. (1999). Trade in financial services: Procompetitive effects and growth performance (No. 99-028/2). Tinbergen Institute Discussion Paper.

French-Davis, R. (2014). Trade Liberalization Strategies and Growth. Reforming Latin America's Economies, 87-114.

Friedman, M. (1968). The role of monetary policy. The American Economic Review, 58(1), 1-17.

Keynes, J. (1936). The General Theory of Employment, Interest and Money. London: Macmillan (reprinted 2007).

Lewa, P. (2006). Market Liberalization in Emerging Economies: Changing Business Practices. Business Practices in Emerging and Re-Emerging Markets, pp 17-42.

Mickiewicz, T. (2009). Political Economy of Reforms. Economics of Institutional Change. Part of the series. Studies in Economic Transition, 53-75

Naranpanawa, A., \& Arora, R. (2014). Does trade liberalization promote regional disparities? Evidence from a multiregional CGE model of India. World Development, 64, 339-349. 
Shou, H. (2015). Liberalization and Reregulation in a Globalized Economy. Fudan Journal of the Humanities and Social Sciences, 8(2), 319-324.

Stigler, G. (1971). The theory of regulation. Bell J Econ Manag Sci, 2, 3-21.

Tornell, A., Westermann, F., \& Martinez, L. (2004). The positive link between financial liberalization, growth and crises (No. w10293). National Bureau of Economic Research. 